\title{
A Tutela dos Direitos Fundamentais no Âmbito do Mandado de Detenção Europeu: Análise da Jurisprudência do Tribunal de Justiça da União Europeia
}

\author{
The Protection of Fundamental Rights under the European \\ arrest warrant: An examination of the case law of the \\ Court of Justice of the European Union
}

\section{Celso Costa Lima Verde Leal ${ }^{1}$}

Faculdade de Direito da Universidade de Coimbra - Coimbra/Portugal celsolimaverde@hotmail.com http://lattes.cnpq.br/4970898293416404

https://orcid.org/0000-0002-8196-5810

\begin{abstract}
Resumo: O presente trabalho analisa o mandado de detenção europeu e a forma como a jurisprudência do Tribunal de Justiça da União Europeia tem garantido a proteção dos direitos fundamentais no processo de entrega, diante da inexistência de hipótese de recusa por violação de direito fundamental. Para isso, inicialmente será feita uma breve análise das regras do mandado de detenção europeu. Na sequência, será analisada a jurisprudência do Tribunal de Justiça da União Europeia sobre o tema, com destaque para os casos Pál Aranyosi e Robert Căldăraru. Palavras-chave: Direitos Fundamentais; Mandado de Detenção; Cooperação Judiciária Internacional.
\end{abstract}

ABSTRACT: The present work analyzes the European arrest warrant and the way in which the jurisprudence of the Court of Justice of the European Union has guaranteed the protection of the fundamental rights in the surrender procedures, due to the absence of possibility of refusal for violation of fundamental right. To do this, a brief analysis of the rules of the European arrest warrant will initially

1 Doutorando em Direito pela Faculdade de Direito da Universidade de Coimbra. Mestre em Direito pela Universidade Federal do Amapá. Especialista em Direito Público pela Universidade de Brasília. Graduado em Direito pela Universidade de Fortaleza. Procurador da República. 
be carried out. The case law of the Court of Justice of the European Union on the subject will be examined, in particular the cases of Pál Aranyosi and Robert Căldăraru.

KEYwoRDs: Fundamental Rights; European Arrest Warrant; International Judicial Cooperation.

SUMÁRIo: Introdução; 1. O mandado de detenção europeu; 2. O Tribunal de Justiça da União Europeia e a tutela dos Direitos Fundamentais; 2.1. Os direitos fundamentais na União Europeia; 2.2. O Tribunal de Justiça da União Europeia e os direitos fundamentais; 2.3. O Tribunal de Justiça da União Europeia e interpretação do direito europeu; 3. A proteção dos Direitos Fundamentais no âmbito do MDE: análise da jurisprudência do TJUE; 3.1. Casos Pál Aranyosi e Robert Căldăraru; 3.2. Decisão do Tribunal de Justiça da União Europeia; 3.3. Análise da decisão do Tribunal de Justiça da União Europeia; 4. Considerações finais; Referências.

\section{INTRODUÇÃO}

As Comunidades Europeias e posteriormente a União Europeia (UE) impuseram significativos avanços na integração dos Estados-Membros (EMs), com implementação da livre circulação de mercadorias, serviços e pessoas. Entretanto, a criminalidade também se beneficiou desse contexto, principalmente a transfronteiriça, o que exigiu a evolução no enfrentamento da criminalidade, especialmente a organizada, com novas formas de investigações e compartilhamento de informações entre autoridades.

O mesmo caminho se buscou para a extradição, sendo aperfeiçoada quando utilizada entre EMs da UE. Porém, mesmo assim, permaneceu um mecanismo lento e burocrático. A resposta do legislador europeu veio com o Conselho Europeu de Tampere, onde o princípio do reconhecimento mútuo das decisões judiciais dos EMs foi destacado como pedra angular do sistema de cooperação judiciária da UE. Na sequência, a Decisão-Quadro (DQ) 2002/584 que criou o Mandado de Detenção Europeu (MDE), por meio do qual, nas relações entre EMs, abandona-se a extradição por 
uma nova sistemática uniforme de rendição, baseada nos princípios da confiança recíproca e do reconhecimento mútuo².

Esse novo mecanismo é significativamente mais simples e ágil que a extradição, somente podendo não ser executado nas taxativas hipóteses facultativas e obrigatórias. Entretanto, a DQ não previu uma hipótese residual de não execução em caso de violação de direito fundamental (DF), apesar de diversas referências em seu texto sobre o respeito a esses direitos.

Ocorre que, em suas normas nacionais de transposição, alguns EMs previram hipótese residual de não execução por violação de DF, enquanto outros EMs se limitaram a repedir as hipóteses da DQ. Como consequência, o Tribunal de Justiça da União Europeia (TJUE) por vezes foi chamado para esclarecer se poderia um EM não executar o MDE por hipótese não prevista na $\mathrm{DQ}^{3}$.

Inicialmente, o TJUE se manifestou pela impossibilidade, fundamentando-se no princípio do reconhecimento mútuo. Entretanto, no julgamento dos casos Pál Aranyosi e Robert Căldăraru, adotou-se nova posição, relativizando o princípio, com importantes consequências na utilização do MDE, conforme trataremos.

\section{O MANDAdo DE DETENÇÃo EUROPEU}

Enquanto entidades meramente econômicas, no direito das Comunidades Europeias não existiam normas de cooperação judiciária em matéria penal, sendo o tema regulado no âmbito europeu pela Convenção Europeia de Extradição de 1957, seus dois Protocolos e por normas posteriores ${ }^{4}$.

2 CONSELHO DA UNIÃO EUROPEIA. 2002/584/JAI: Decisão-quadro do Conselho, de 13 de Junho de 2002, relativa ao mandado de detenção europeu e aos processos de entrega entre os Estados-Membros. Considerando n. ${ }^{\circ}$ 6. Disponível em: <http://eur-lex.europa.eu/legal-content/PT/TXT/HTML/?uri=CELEX:32002F0584\&from=PT>. Acesso em 15 mai. 2019.

3 CONSELHO DA UNIÃO EUROPEIA. 2002/584/JAI: Decisão-quadro do Conselho, de 13 de Junho de 2002, relativa ao mandado de detenção europeu e aos processos de entrega entre os Estados-Membros. Considerando n. ${ }^{\circ}$ 6. Disponível em: <http://eur-lex.europa.eu/legal-content/PT/TXT/HTML/?uri=CELEX:32002F0584\&from=PT>. Acesso em 15 mai. 2019.

4 CAEIRO, Pedro. Cooperação judiciária na União Europeia. In: Direito penal económico e europeu: Textos doutrinários. Coimbra: Editora Coimbra, v. 
Essa realidade muda com o Tratado de Maastricht (1992) e o estabelecimento da estrutura de três pilares da UE, quando a cooperação judiciária passa a ser tratada como questão de interesse comum sob o terceiro pilar ${ }^{5}$. Nessa nova formatação, são promulgadas as Convenções de Extradição de Bruxelas ${ }^{6}$ (1995) e $\operatorname{Dublin}^{7}(1996)^{8}$.

III, 2009, f. 70, cita como exemplos Convenção Europeia de Auxílio Mútuo em Matéria Penal (1959), Convenção Europeia para a Vigilância de Pessoas Condenadas ou Libertadas Condicionalmente (1964), Convenção Europeia sobre o Valor Internacional das Sentenças Penais (1970); Convenção Europeia sobre Transmissão de Processos Penais (1972), Convenção Europeia para Repressão ao Terrorismo (1977) e Convenção relativa à Transferência de Pessoas Condenadas (1983).

5 Sobre a estrutura de pilares da União Europeia, MACHADO, Jónatas Eduardo Mendes. Direito da União Europeia. Coimbra: Editora Coimbra. $2^{\text {a }}$ Edição. 2014, p. 20, dispõe que: O tratado UE procurou dar mais um passo no sentido de união política, com especial incidência nos âmbitos da cooperação em matéria de política externa e de defesa ( $2^{\circ}$ pilar) e da justiça e da administração interna ( $3^{\circ}$ pilar). O objetivo final consistiu em erguer a UE sob três pilares. O primeiro, relativo às comunidades, e servido pela unificação parcial no plano institucional, para elevação do Tribunal de Contas a órgão principal e comum e pelo alargamento do controlo jurisdicional. Acolhida foi a nova designação de CE, em substituição de CEE. A este acrescentam-se o segundo e terceiro pilares. O primeiro diz respeito à chamada Política Externa e de Segurança Comum (PESC), integrando o Comité Político e o Senhor "PESC". O terceiro pilar, de cooperação em matéria de cooperação policial e judiciária em matéria penal, assenta no Comité K4, e tem domínios da Cooperação a 1) política de asilo; 2) o controlo das fronteiras exteriores; 3 ) a política de imigração; 4) a luta contra a toxicodependência; 5) a luta contra a fraude; 6) a cooperação judiciária em matéria civil e penal; 7) a cooperação aduaneira; 7) a cooperação policial.

6 UNIÃO EUROPEIA. Council Act of 10 March 1995. Disponível em: <eur-lex. europa.eu/legal-content/EN/TXT/?uri=LEGISSUM:114015a >. Acesso em 14 mai 2019, prevê um procedimento simplificado de entrega em caso de concordância da pessoa interessado e do Estado requerido.

7 UNIÃO EUROPEIA. Convenção estabelecida com base no artigo K.3 do Tratado da União Europeia, relativa à extradição entre os Estados-membros da União Europeia. Disponível em: <eur-lex.europa.eu/legal-content/PT/ TXT/HTML/?uri=CELEX:41996A1023(02)\&from=EN>. Acesso em 14 mai 2019. Simplifica os procedimentos de entrega e reduz as hipóteses de recusa de extradição.

8 CAEIRO, Pedro. Cooperação judiciária na União Europeia. In: Direito penal económico e europeu: Textos doutrinários. Coimbra: Editora Coimbra, v. 3, 2009, f. 70. 
No Conselho Europeu de Tampere, adota-se o princípio do reconhecimento mútuo, podendo-se falar na semente do que viria a ser o MDE, que é formalmente criado pela DQ 2002/584, quando se abandona a antiga extradição por uma nova sistemática uniforme de rendição, baseada nos princípios da confiança recíproca e do reconhecimento mútuo, significativamente mais simples e ágil que a forma anterior, com redução das hipóteses de não execução9 ${ }^{9}$ o que constituiu um dos seus aspectos mais importantes ${ }^{10}$.

Sua adoção decorre de um estreitamento das relações entres os EMs que permitiu uma gradual abolição de entraves jurídicos tradicionais e simplificação dos procedimentos de cooperação ${ }^{11}$. Passa-se para uma relação de parceria entre EMs, não mais se falando em Estado-requerente e Estado-requerido, mas em Estado de emissão e Estado de execução, o que sugere o fim dos processos de validação e exequatur ${ }^{12}$.

Outra grande revolução do MDE em comparação à extradição clássica é que o diálogo não se dá mais entre Estados soberanos, mas sim entre juízes independentes, com contato direto entre as autoridades judiciais (e não executivas) ${ }^{13}$. Isso significa que a manutenção de uma detenção obedece às mesmas condições do direito processual penal nacional, permitindo adoção de outras medidas destinadas a prevenir a fuga da pessoa ${ }^{14}$, evitando-se detenções desnecessárias.

9 SCHALLMOSER, Nina Marlene. The European arrest warrant and Fundamental Rights. Risks of Violation of Fundamental Rights through the EU Framework Decision in Light of the ECHR. European Journal of Crime, Criminal Law and Criminal Justice, v. 22, 2014, p. 136.

10 RODRIGUES, Anabela Miranda. O direito penal europeu emergente. Coimbra: Editora Coimbra. 2008, p. 195.

11 FICHERA, Massimo. The European arrest warrant and the Sovereign State: A Marriage of Convenience?. European Law Journal, Oxford, v. 15, n. 1, 2009 , p 72.

12 RODRIGUES, Anabela Miranda. O direito penal europeu emergente. Coimbra: Editora Coimbra. 2008, p. 71.

13 FICHERA, Massimo. The European arrest warrant and the Sovereign State: A Marriage of Convenience?. European Law Journal, Oxford, v. 15, n. 1, 2009, p 78.

14 RODRIGUES, Anabela Miranda. A globalização do direito penal - Da pirâmide à rede ou entre a unificação e a harmonização. In Direito penal económico e europeu: Textos doutrinários. Editora Coimbra, v.3, 2009, p. 169. 
Seu procedimento é extremamente simples, tendo início com a expedição de um MDE pela autoridade judiciária de emissão a partir de um mandado de prisão pretérito emitido com base no direito do Estado de emissão ${ }^{15}$. Após cumprimento de formalidade, o que pode incluir a tradução, o MDE é encaminhado para autoridade judiciária de execução, definida pelo direito do EM de execução. Pode haver a inclusão pela autoridade judiciária de emissão da pessoa procurada no Sistema de Informação Schengen (SIS) ${ }^{16}$. À autoridade judiciária de execução cabe apenas analisar a presença de alguma hipótese de não execução (facultativa ou obrigatória). Havendo necessidade, poderá a autoridade judiciária de execução solicitar informações complementares para decidir sobre a execução do $\mathrm{MDE}^{17}$. Recebidas as informações, deve a autoridade judiciária de execução decidir sobre a entrega ${ }^{18}$ no prazo

15 TRIBUNAL DE JUSTIÇA DA UNIÃO EUROPEIA. Acórdão C-241/2015, $1^{\circ}$ de junho de 2016. Disponível: <eur-lex.europa.eu/legal-content/PT/TXT/?qid $=1557868945504 \& u r i=C E L E X: 62015 C A 0241>$. Acesso em 14 mai. 2019, o TJUE já decidiu que, antes da emissão do MDE, deve existir um mandado de detenção nacional distinto do MDE, sob pena de não validade do MDE.

16 EUROPEIA, Comissão. Comunicado de Imprensa. Disponível: <europa.eu/ rapid/press-release_IP-13-309_pt.htm>. Acesso em 14 mai. 2019: O SIS permite um intercâmbio fácil de informações entre as autoridades nacionais de controlo das fronteiras, as autoridades aduaneiras e a polícia sobre pessoas que possam ter estado envolvidas em crimes graves. O sistema contém igualmente alertas sobre pessoas desaparecidas, em particular crianças, bem como informações sobre determinados bens, como notas de banco, automóveis ligeiros, furgonetas, armas de fogo e documentos de identidade que tenham sido roubados, ilegalmente utilizados ou perdidos.

17 CONSELHO DA UNIÃO EUROPEIA. 2002/584/JAI: Decisão-quadro do Conselho, de 13 de Junho de 2002, relativa ao mandado de detenção europeu e aos processos de entrega entre os Estados-Membros. Artigo 15², 2. Disponível em: <http://eur-lex.europa.eu/legal-content/PT/TXT/HTML/?uri=CELEX:32002F0584\&from=PT>. Acesso em 15 mai. 2019.

18 Sobre a diferença entre entrega e extradição, CAEIRO, Pedro. O procedimento de entrega previsto no Estatuto de Roma e sua incorporação no Direito português. IN: MOREIRA, Vital. O Tribunal Penal Internacional e ordem jurídica portuguesa. Coimbra: Editora Coimbra, 2004, 73: afirma: A ideia fez caminho e acabou por encontrar consagração forma no Estatuto de Roma. De acordo com a definição do artigo $102^{\circ}$ do do Estatuto, na sua versão portuguesa, "por entrega entende-se a entrega [sic] de uma pessoa por um Estado ao Tribunal, nos termos do presente Estatuto; por extradição entende-se a entrega de uma pessoa por um Estado a outro Estado, conforme previsto num tratado, numa 
de sessenta dias ou dez dias se a pessoa aceitar ser entregue, ambos contando da data da prisão ${ }^{19}$.

Verifica-se que, apesar de fundado no reconhecimento mútuo, a execução do MDE, em certos aspectos, adotou uma posição moderada, não sendo sua execução automática, o que autoriza uma análise pela autoridade judiciária de execução se estão presentes hipóteses de não execução, numa tentativa de salvaguarda das liberdades fundamentais ${ }^{20}$.

As hipóteses de não execução obrigatória são três, podendo ser resumidas como: anistia; bis in idem e impossibilidade responsabilização penal por idade. Por sua vez, as hipóteses de não execução facultativa são várias, não justificando sua transcrição ${ }^{21}$.

convenção ou no direito interno". Já COSTA, João Pedro Lopes. A dupla incriminação no mandado de detenção europeu e o verdadeiro alcance da abolição do seu controlo. In: Temas de Extradição e Entrega. Coimbra: Editora Almedina, 2015. p. 87, afirma: Também o denominado aligeiramento das condições de entrega reflecte o intuito de maximação e efectividade da cooperação entre autoridades judiciárias dos Estados-Membros, cuja concretização está patente no enunciado de motivos de não execução obrigatória e facultativa do MDE (arts. $3^{\circ}$ e $4^{\circ}$ da DQ, respectiamente), menos exigente quando comparado com os tradicionais motivos de recusa do pedido de extradição.

19 CONSELHO DA UNIÃO EUROPEIA. 2002/584/JAI: Decisão-quadro do Conselho, de 13 de Junho de 2002, relativa ao mandado de detenção europeu e aos processos de entrega entre os Estados-Membros. Considerando n. ${ }^{\circ}$ 6. Disponível em: <http://eur-lex.europa.eu/legal-content/PT/TXT/HTML/?uri=CELEX:32002F0584\&from=PT >. Acesso em 15 mai. 2019.

20 RODRIGUES, Anabela Miranda. O mandado de detenção europeu - Na via da construção de um sistema penal europeu: um passo ou um salto?. Revista Portuguesa de Ciência Criminal, Porto, ano 13, n. 1, 2003, p. 36.

${ }^{21}$ Em resumo: o fato não constituir infracção no EM de execução; a pessoa indicada no MDE está sendo processada pelo mesmo fato no EM de execução; impossibilidade de responsabilização penal pelo fato no EM de execução porque suas autoridades judiciárias decidiram não instaurar procedimento criminal, ou puseram termo ao procedimento instaurado, ou porque a pessoa foi definitivamente julgada; prescrição da acção penal ou da pena nos termos da legislação do EM de execução e os factos forem de sua competência; se a autoridade judiciária souber que a pessoa procurada foi definitivamente julgada pelos mesmos factos por um país terceiro, na condição de que, em caso de condenação, a pena tenha sido cumprida ou esteja actualmente em cumprimento ou não possa já ser cumprida segundo as leis do país de condenação; quando a pessoa procurada se encontrar no EM de execução for sua nacional ou sua residente e este Estado se comprometa a executar essa pena ou medida de segurança nos termos do seu direito nacional; se a infracção 
Da análise das hipóteses obrigatórias e facultativas de não execução do MDE, constata-se que não foi prevista uma hipótese residual de não execução por violação de DFs. Trata-se de significativa mudança em relação ao sistema da Convenção Europeia de Extradição, que previa a chamada "cláusula humanitária"22.

Não parece mero esquecimento do legislador europeu, mas opção fundada na confiança mútua e no postulado do respeito efetivo pelos DFs em toda $\mathrm{UE}^{23}$, o que tem gerando grande debate doutrinário e jurisprudencial, além de divergência entre as normas internas dos EMs.

Apesar da omissão, o art. $1 .^{\circ}$, n. ${ }^{\circ} 3$, da DQ 2002/584, impõe o respeito aos DFs e aos princípios previstos no artigo $6 .^{\circ}$ do Tratado da União Europeia, o que poderia conduzir os EMs, em suas Leis de transposição, a consagrarem motivo de recusa fundado no não respeito aos $\mathrm{DFs}^{24}$.

Diante desse contexto, existem duas formas de interpretação. A primeira no sentido de que as previsões impõem o respeito aos DFs, podendo resultar em recusa de execução. A segunda interpretação seria no sentido de que a DQ previu hipóteses taxativas de não execução por violação dos DFs, não podendo ser ampliadas ${ }^{25}$.

tenha ocorrido, no todo ou em parte, no seu território ou em local considerado como tal do EM de execução ou tenha sido praticada fora do território do EM de emissão e o direito do EM de execução não autorize o procedimento penal por uma infracção idêntica praticada fora do seu território; se a pessoa não tiver estado presente no julgamento que conduziu à decisão.

CONSELHO DA EUROPA. Convenção Europeia de Extradição, de 13 de dezembro de 1957. Disponível em: <http://www.coe.int/en/web/conventions/full-list/-/conventions/rms/0900001680064587>. Acesso em 15 mai. 2019.

RODRIGUES, Anabela Miranda. O mandado de detenção europeu - Na via da construção de um sistema penal europeu: um passo ou um salto?. Revista Portuguesa de Ciência Criminal, Porto, ano 13, n. 1, 2003, p. 46.

CONSELHO DA UNIÃO EUROPEIA. 2002/584/JAI: Decisão-quadro do Conselho, de 13 de Junho de 2002, relativa ao mandado de detenção europeu e aos processos de entrega entre os Estados-Membros. Considerando 13. Disponível em: <http://eur-lex.europa.eu/legal-content/PT/TXT/HTML/?uri=CELEX:32002F0584\&from=PT>. Acesso em 15 mai. 2019.

25 FICHERA, Massimo. The European arrest warrant and the Sovereign State: A Marriage of Convenience?. European Law Journal, Oxford, v. 15, n. 1, 2009, p. 95. 
Embora a previsão de hipótese de não execução do MDE por violação dos DFs resultasse numa menor efetividade do MDE e do próprio princípio da confiança recíproca, os DFs não podem ser negados mutuamente, enquanto baseados no princípio da conservação e da produção normativa ${ }^{26}$, logo, não teria o legislador europeu discricionariedade de fazê-lo. Esse segundo entendimento parece ser razoável em algumas situações, sob pena de comprometer o sistema europeu de proteção ${ }^{27}$, pois, apesar de a UE estar fundada nos princípios de liberdade, democracia, respeito pelos direitos humanos e pelas liberdades fundamentais, não existiria mecanismo capaz de garantir a observância dos princípios na execução do MDE.

Como resultado do exposto, alguns EMs optaram apenas por reproduzir as hipóteses de não execução previstas na DQ, por entender que o sistema de proteção dos direitos fundamentais da UE seria suficiente (República-Checa, Romênia, Estónia, Luxemburgo, Hungria, Polónia e Eslováquia). Outros EMs optaram por prever hipótese de não execução quando possa resultar em violação de DF do interessado (Itália, Holanda, Alemanha, Reino Unido) ${ }^{28}$. Por fim, temos o caso de Portugal, que previu hipótese de recusa por violação de direito fundamental mais restrita, mas posteriormente a excluiu ${ }^{29}$. A jurisprudência portuguesa não tem admitido outras hipóteses de não execução além das previstas na DQ e Lei $65 / 2003^{30}$.

26 FORST, Rainer. The justification of basic rights: A discourse-theoretical approach. Netherlands Journal of Legal Philosophy, v. 45, 2016, p. 13.

27 FICHERA, Massimo. The European arrest warrant and the Sovereign State: A Marriage of Convenience?. European Law Journal, Oxford, v. 15, n. 1, 2009, p. 82.

28 KLIMEK, Libor. New law on the European arrest warrant in the Slovak Republic: does it fulfil standards at the level of the EU. European Journal of Crime \& Criminat Law and Criminat Justice. v. 20, 2012, p. 185-186.

29 PORTUGAL. Lei 65, de 23 de agosto de 2003: aprova o regime jurídico do mandado de detenção europeu. Disponível em: <http://www.pgdlisboa.pt/ leis/lei_mostra_articulado.php?nid=298\&tabela=leis $>$. Acesso em 15 mai. 2019, em seu artigo $11 .^{\circ}$, d, previa como motivo de recusa de execução do MDE a infração ser punível com pena de morte ou outra pena que resulte em lesão irreversível da integridade física e quando o MDE for emitido por motivos políticos. Entretanto, a Lei n. ${ }^{\circ}$ 35/2015 revogou as duas hipóteses.

30 Nesse sentido decisão do TRIBUNAL DA RELAÇÃO DE GUIMARÃES. Processo n. ${ }^{\circ}$ 11/10.8YRGMR. Relator Cruz Bucho, Guimarães, 21 de 
A não harmonização das normas nacionais certamente resultaria em divergência na utilização do MDE pelos EMs, o que de fato ocorreu, cabendo ao TJUE definir a interpretação a ser adotada em toda EU.

\section{O Tribunal de Justiça da União Europeia e a tutela dos Direitos Fundamentais}

Apesar da opção do legislador europeu em limitar as hipóteses de não execução do MDE ir ao encontro do princípio do reconhecimento mútuo, subsiste o risco de graves violações aos direitos dos indivíduos, cabendo ao TJUE buscar um equilíbrio. Antes de analisarmos a posição da corte, convém uma breve análise da evolução dos DFs na UE e na jurisprudência do TJUE, bem como a corte tem se utilizado do reenvio prejudicial nesse contexto.

\subsection{Os DiREITOS FUNDAMENTAIS NA UNIÃo EUROPEIA}

Os objetivos iniciais do que viria a ser a UE eram estritamente econômicos, o que justificava a ausência de previsões de direitos e garantias fundamentais, salvo aqueles relacionados aos seus objetivos iniciais (liberdade de circulação de pessoas, bens e capitais e de estabelecimentos) $)^{31}$. Nesse período, ao Conselho da Europa competia a proteção dos DFs.

Ainda que a jurisprudência do TJUE tenha reconhecido os DFs no âmbito das Comunidades Europeias ${ }^{32}$, somente com o Tratado de Maas-

dezembro de 2010. Disponível em: <http://dre.pt/web/guest/pesquisa/-/ search/94592875/details/normal?q=Processo+n. ${ }^{\circ} \% 2011 \% 2$ F10.8YRGMR>. Acesso em 14 mai. 2019; e do TRIBUNAL DE RELAÇÃO DE LISBOA. Processo n. ${ }^{\circ}$ 836/14.5YRLSB-9 e 546/17.1YRLSB-5. Relator Abrunhosa de Carvalho, Lisboa, 02 de outubro de 2014. Disponível em: <http://dre. pt/web/guest/pesquisa/-/search/99136875/details/normal?q=Processo+n. ${ }^{\circ} \% 20836 \% 2 F 14.5$ YRLSB-9>. Acesso em 14 mai. 2019.

31 MOREIRA, Vital. A 'Constitucionalização' dos Direitos Fundamentais na União Europeia (UE). In: Estudos em Homenagem ao Conselheiro José Manuel Cardoso da Costa. Coimbra: Coimbra Editora, 2003, f. 697.

32 MOURA RAMOS, Rui Manuel Moura. Situação e Desafios da Protecção dos Direitos Fundamentais na União Europeia. Disponível em: <http://scielo. 
tricht, o Tratado da União Europeia passa a ter um artigo dedicado aos DFs $\left(\operatorname{art} . \mathrm{F}, \mathrm{n} .{ }^{\mathrm{o}} 2^{\mathrm{o}}\right)^{33}$, assim como surge o conceito de cidadania europeia ${ }^{34}$. Com o Tratado de Amsterdã, ocorre alteração do art. $6 .^{\circ}$ do Tratado da União Europeia (ex-artigo F) relativo aos DFs e há o surgimento do art. $7^{\circ}$, que prevê formas de sanções aos EMs que os desrespeitem. O tratado de Nice possibilitou aplicação de sanções aos EMs de forma preventiva. A Carta de Direitos Fundamentais da União Europeia (Carta) é adotado em 2000, mas sem força vinculante ${ }^{35}$, ainda que, segundo o TJUE, possuísse status de soft low, o que lhes permitia produzir efeitos jurídicos ${ }^{36}$.

mec.pt/scielo.php?script=sci_arttext\&pid=S2183-184X2018000200002. Acesso em: 02 jan. 2019.

33 UNIÃO EUROPEIA. Tratado da União Europeia. Artigo F, n. 2. Disponível em: <eur-lex.europa.eu/legal-content/PT/TXT/?uri=CELEX:11992M/TXT>. Acesso em 14 maio de 2019: 2. A União respeitará os direitos fundamentais tal como os garante a Convenção Europeia de Salvaguarda dos Direitos do Homem e das Liberdades Fundamentais, assinada em Roma em 4 de novembro de 1950, e tal como resultam das tradições constitucionais comuns aos Estados-Membros, enquanto princípios gerais do direito comunitário.

RODRIGUES Anabela Miranda; DA MOTA, José Luís Lopes. Para uma política criminal europeia. Coimbra: Editora Coimbra. 2002, p. 33.

35 MOURA RAMOS, Rui Manuel Moura. Situação e Desafios da Protecção dos Direitos Fundamentais na União Europeia. Disponível em: http://scielo.mec. pt/scielo.php?script=sci_arttext\&pid=S2183-184X2018000200002. Acesso em: 02 jan. 2019.

36 Sobre o tema TRIBUNAL DE JUSTIÇA DA UNIÃO EUROPEIA. Conclusões da Advogada-Geral Eleanor Sharpston, Processo C-396/11, de 12 de outubro de 2012. Disponível em:<http://eur-lex.europa.eu/legal-content/PT/ TXT/?qid=1557865541872\&uri=CELEX:62011CC0396>. Acesso em 14 mai. 2019: 48. Embora a Carta tenha sido proclamada solenemente em Nice, em 7 de dezembro de 2007, a decisão quanto ao estatuto jurídico preciso a atribuir-lhe foi adiada. Consequentemente, a Carta não foi incluída em nenhum dos Tratados e às suas disposições não foi conferido valor legislativo por nenhuma outra forma. Não obstante, a Carta passou rapidamente a ser considerada um catálogo autorizado de direitos fundamentais, porque confirmou os princípios gerais inerentes ao Estado de Direito que são comuns às tradições constitucionais dos Estados-Membros. O Tribunal de Justiça inspirou-se frequentemente nas disposições da Carta para proferir os seus acórdãos. Consequentemente, a Carta adquiriu o estatuto de «soft law»; ou seja, embora as suas disposições não fossem diretamente aplicáveis enquanto parte do direito da UE, eram suscetíveis de produzir efeitos jurídicos - em muitos casos, efeitos amplos - no interior da União. 
O Tratado de Lisboa, em seu art. $6 .^{\circ}$, expressamente reconhece que os direitos, as liberdades e os princípios enunciados na Carta têm o mesmo valor jurídico dos Tratados. O mesmo artigo qualifica os DFs garantidos pela Convenção Europeia dos Direitos do Homem (CEDH) como princípios gerais da legislação da UE, o que tem como consequência que as normas da UE podem e devem ser produzidas e interpretadas em consonância com eles. Por sua vez, o artigo 51. ${ }^{\circ}$, n. ${ }^{\circ} 1$, da Carta afirma que suas disposições são dirigidas às instituições e aos órgãos da União, o que inclui os órgãos legislativos, o que significou um grande avanço no reconhecimento de DF por parte da UE, com importantes consequências práticas ${ }^{37}$.

\subsection{O TRIBUNAL DE JUSTIÇA DA UNIÃo EUROPEIA E OS DIREITOS FUNDAMENTAIS}

Conforme visto, dentro do contexto inicial das Comunidades Europeias, com perfil estritamente econômico, em que a preocupação com os direitos fundamentais era deixado a cargo do Conselho da Europa, o então Tribunal de Justiça das Comunidades Europeias, num primeiro momento, decidiu que lhe faltava competência para avaliar controvérsias sobre DFs, por entender que os tratados não abordavam o tema e que não poderia considerar a regulamentação constitucional dos EMs diante da supremacia do direito comunitário. Porém, a tese da primazia do direito comunitário $^{38} \mathrm{em}$ relação ao direito nacional não foi bem recebida por alguns EMs, sobretudo Itália e Alemanha, por não aceitarem se submeterem ao direito comunitário até que este dispusesse de proteção adequada aos DFs no mesmo patamar de seus ordenamentos constitucionais.

37 EUROPEIA, União. Tratado de Lisboa: Tratado da União Europeia 2009. Disponível em < https://www.parlamento.pt/europa/Documents/Tratado_ Versao_Consolidada.pdf $>$. Acesso em: 15 mai. 2019.

38 MACHADO, Jónatas Eduardo Mendes. Direito da União Europeia. Coimbra: Editora Coimbra. $2^{\text {a }}$ Edição. 2014, p. 54, sobre a primazia do direito europeu afirma: "A natureza constitucional do direito da UE manifesta-se na primazia do direito da UE sobre o direito nacional, na impossibilidade geral de controlo da constitucionalidade das normas do direito da UE pelos tribunais nacionais e pela previsão de instâncias e mecanismos de controlo jurisdicional, no seio da UE, da validade dos respectivos actos de direito derivado". 
Como consequência, os Tribunais Constitucionais desses EMs passaram a admitir a possibilidade de submissão do direito comunitário às Constituições nacionais, o que representava um sério risco ao próprio direito comunitário, forçando o Tribunal de Justiça das Comunidades Europeias a rever sua posição inicial no julgamento do Processo 29/6939, no qual entendeu que os direitos fundamentais individuais fariam parte do acervo de princípios gerais do direito comunitário. Nos anos seguintes, diversas decisões foram ampliando o âmbito dos direitos fundamentais dentro do direito comunitário: Processo 11/1970 ${ }^{40}$, Processo 4/1973 ${ }^{41}$, Processo 36/1975 ${ }^{42}$, Processo 5/1988 ${ }^{43}$, Processo C-260/198944.

Com o surgimento da UE e a criação de normas de cooperação judiciária entre os EMs no âmbito do terceiro pilar, o TJUE passou a ser demandado por questões de natureza penal. Inicialmente, posicionouse no sentido de autorizar que os DFs poderiam ser comprimidos em

39 TRIBUNAL DE JUSTIÇA DA UNIÃO EUROPEIA. Acórdão n. ${ }^{o}$ 29/1969, de 12 de novembro de 1969. Disponível: <eur-lex.europa.eu/legal-content/ $\mathrm{PT} / \mathrm{TXT}$ /?qid=1557870754232\&uri=CELEX:61969CJ0029>. Acesso em 14 mai. 2019: 7. Interpretada desta forma, a disposição controvertida não revela qualquer elemento susceptível de colocar em causa os direitos fundamentais individuais compreendidos nos princípios gerais do direito comunitário, cuja observância é assegurada pelo Tribunal.

40 TRIBUNAL DE JUSTIÇA DA UNIÃO EUROPEIA. Acórdão n. ${ }^{\circ}$ 11/1970, de 14 de maio de 1974. Disponível: <http://eur-lex.europa.eu/legal-content/ $\mathrm{PT} / \mathrm{TXT}$ /?qid=1557868205849\&uri=CELEX:61970CJ0011>. Acesso em 14 mai. 2019.

41 TRIBUNAL DE JUSTIÇA DA UNIÃO EUROPEIA. Acórdão n. ${ }^{\circ}$ 4/1973, de 17 de dezembro de 1970. Disponível: <eur-lex.europa.eu/legal-content/ $\mathrm{PT} / \mathrm{TXT}$ /?qid=1557868283819\&uri=CELEX:61973CJ0004>. Acesso em 14 mai. 2019.

42 TRIBUNAL DE JUSTIÇA DA UNIÃO EUROPEIA. Acórdão n. ${ }^{\circ}$ 36/1975, de 25 de outubro de 1975. Disponível: <eur-lex.europa.eu/legal-content/ $\mathrm{PT} / \mathrm{TXT} /$ ?qid=1557868367592\&uri=CELEX:61975CJ0036>. Acesso em 14 mai. 2019

43 TRIBUNAL DE JUSTIÇA DA UNIÃO EUROPEIA. Acórdão n. ${ }^{\circ}$ 5/1988, de 13 de julho de 1989. Disponível: <eur-lex.europa.eu/legal-content/PT/TXT/?qid=1557868472344\&uri=CELEX:61988CJ0005> . Acesso em 14 mai. 2019.

44 TRIBUNAL DE JUSTIÇA DA UNIÃO EUROPEIA. Acórdão n. ${ }^{\circ}$ C-260/1989, de 18 de junho de 1989. Disponível: <eur-lex.europa.eu/legal-content/PT/ TXT/?qid=1557868537836\&uri=CELEX:61989CJ0260>. Acesso em 14 mai. 2019. 
determinadas situações, especialmente para atender os objetivos de interesse geral da UE, mas sem analisar detalhadamente a conformidade da norma da UE com os DFs, conforme decidido no caso Bosphorus ${ }^{45}$. Esse posicionamento somente foi alterado no ano de 2005 no julgamento dos casos Kadi $\mathrm{I}^{46}$ e Kadi $\mathrm{II}^{47}$, quando o TJUE reconheceu que algumas normas de direito europeu estavam em desconformidade com os direitos fundamentais ${ }^{48}$.

Com o Tratado de Amsterdã, o TJUE ganha importantes poderes, incluindo o de decidir a título precário sobre a validade e a interpretação das DQs, assim como o de fiscalizar sua legalidade ${ }^{49}$. Já no Tratado de

45 TRIBUNAL DE JUSTIÇA DA UNIÃO EUROPEIA. Acórdão n. ${ }^{\circ}$ C-84/1995, de 30 de julho de 1996. Disponível: <eur-lex.europa.eu/legal-content/PT/ $\mathrm{TXT}$ ?qqid=1557868701487\&uri=CELEX:61995CJ0084>. Acesso em 14 mai. 2019: 21. Deve recordar-se que, segundo jurisprudência constante, os direitos fundamentais invocados pela Bosphorus Airways não se apresentam como prerrogativas absolutas e o seu exercício pode ser objecto de restrições justificadas por objectivos de interesse geral prosseguidos pela Comunidade (v. acórdãos de 13 de Dezembro de 1979, Hauer, 44/79, Recueil, p. 3727; de 13 de Julho de 1989, Wachauf, 5/88, Colect., p. 2609, e de 5 de Outubro de 1994, Alemanha/Conselho, C-280/93, Colect.

46 TRIBUNAL DE JUSTIÇA DA UNIÃO EUROPEIA. Acórdão n. ${ }^{\circ}$ T-315/01, de 21 de setembro de 2005. Disponível: <http://eur-lex.europa.eu/legal-content/PT/TXT/?qid=1557865933229\&uri=CELEX:62001TJ0315>. Acesso em 14 mai. 2019.

47 TRIBUNAL DE JUSTIÇA DA UNIÃO EUROPEIA. Acórdão T-85/09, de 30 de setembro de 2010 Disponível: <http://eur-lex.europa.eu/legal-content/PT/TXT/?qid=1557866147004\&uri=CELEX:62009TA0085>. Acesso em 14 mai. 2019.

O caso tem origem a partir da implantação pela UE de Resoluções da Organização das Nações Unidas que determinavam o congelamento de fundos financeiros de pessoas individuais e coletivas suspeitas de terem ligações com o Osama bin Laden, Al-Qaeda e Talibãs, sem possibilidade de qualquer contestação por parte dos interessados. No primeiro julgamento, o Tribunal de primeira instância decide que não poderia julgar medidas do Conselho de Segurança da ONU. Já no Tribunal de Justiça entendeu que não se tratava de analisar a Resolução do Conselho de Segurança da ONU, mas sim as disposições comunitárias que deram que executaram, logo que não poderiam violar direito fundamental.

49 CAEIRO, Pedro. Cooperação judiciária na União Europeia. In: Direito penal económico e europeu: Textos doutrinários. Coimbra: Editora Coimbra, v. 3, 2009 , f. 75 . 
Lisboa, o TJUE se consagrou como órgão jurisdicional da UE. Com sede em Luxemburgo, é composto por 28 juízes (cada um indicado por um Estado-Membro) e 11 Advogados-Gerais, designados para mandatos de seis anos. Ao TJUE cabe a responsabilidade de interpretar, de forma autorizada e unificadora, as normas da $\mathrm{UE}^{50}$.

\subsection{O TRIBUNAL DE JUSTIÇA DA UNIÃo EUROPEIA E INTERPRETAÇÃO DO DIREITO EUROPEU}

As atribuições do TJUE são muitas, interessando ao caso sua competência prejudicial exercida por meio do reenvio prejudicial ${ }^{51}$.

O direito da UE tem significativo impacto no cotidiano dos indivíduos e das empresas, resultando inevitavelmente em litígios nos tribunais nacionais, o que poderia pulverizar a hermenêutica do direito europeu. Por meio do reenvio prejudicial ${ }^{52}$, o TJUE busca garantir a efetividade do

50 MACHADO, Jónatas Eduardo Mendes. Direito da União Europeia. Coimbra:

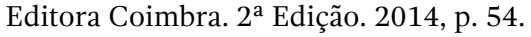

51 Sobre o tema, MACHADO, Jónatas Eduardo Mendes. Direito da União Europeia. Coimbra: Editora Coimbra. $2^{\text {a }}$ Edição. 2014, p. 639 afirma: A decisão de reenvio é da responsabilidade do órgão jurisdicional de reenvio (iudex a qua). Este deve fornecer o TJUE (iudex ad quem) um quadro fático e normativa completo e detalhado do litígio do processo principal e responder aos pedidos de esclarecimentos que lhe sejam dirigidos pela instância da UE. A instância jurisdicional nacional deve, além disso, explicar as razões da pertinência da questão à resolução do litígio. Isso significa que, em muitos casos, o reenvio deve ser feito após a fixação da matéria de facto, posteriormente à instrução e antes do julgamento, preferencialmente depois de um debate contraditório. No entanto, o reenvio é admissível em qualquer fase do processo. Cabe exclusivamente ao tribunal nacional decidir quando o acha oportuno.

52 Sobre o tema, MACHADO, Jónatas Eduardo Mendes. Direito da União Europeia. Coimbra: Editora Coimbra. 2a Edição. 2014, p. 624 diz: "No direito da UE, o reenvio prejudicial, ou referência preliminar, constitui o mecanismo por excelência de cooperação judicial, ou diálogo judicial, entre os tribunais nacionais dos Estados-Membros e a jurisdição da UE. Trata-se de uma peça fundamental de um sistema descentralizado de proteção jurisdicional. A utilização deste meio processo transforma os tribunais dos Estados-Membros em instrumentos de realização do direito da UE, de acordo com o princípio de desdobramento funcional anteriormente mencionado. Os tribunais nacionais, dotados de autoridade europeia, ajudam o TJUE a defender a primazia do direito da UE contra os localismos e as forças centrífugas. Assim é, não obstante 
direito da UE e de sua primazia em face do direito nacional, através de uma interpretação vinculativa aos órgãos da UE e a todos os EMs, sendo isso fundamental para subsistência da UE e da própria ordem jurídica que disciplina e estrutura ${ }^{53}$.

$\mathrm{O}$ reenvio prejudicial permite que um tribunal nacional ${ }^{54}$, confrontado com lide que envolva direito da UE, envie ao TJUE questão sobre interpretação do direito da UE ou sobre validade e interpretação dos atos adotados pelas instituições, pelos órgãos ou pelos organismos da União. Ao TJUE cabe apenas a análise da tese jurídica. Ao tribunal nacional compete aplicar a interpretação dada pelo TJUE ao caso concreto ${ }^{55}$.

$\mathrm{Na}$ interpretação das normas decorrentes das DQs, a participação do TJUE é imprescindível, pois, apesar de os tribunais nacionais terem competência para interpretar as normas nacionais decorrentes da DQ, eventual interpretação pode divergir de outro tribunal nacional,

não existir hierarquia entre os tribunais da UE e os tribunais nacionais e de existir uma separação funcional entre eles. A verdade é que os tribunais nacionais integram hoje a categoria dos tribunais da UE em sentido amplo.

53 MACHADO, Jónatas Eduardo Mendes. Direito da União Europeia. Coimbra: Editora Coimbra. $2^{\text {a }}$ Edição. 2014, f. 54.

${ }^{54}$ Sobre o conceito de órgão jurisdicional para fins de reenvio prejudicial, MACHADO, Jónatas Eduardo Mendes. Direito da União Europeia. Coimbra: Editora Coimbra. $2^{\text {a }}$ Edição. 2014, f. 630, dispõe: com base nesses elementos conotativos, podemos identificar alguns candidatos positivos e negativos ao conceito de órgão jurisdicional de reenvio. Candidatos positivos podemos assinalar, com a ajuda da jurisprudência do TJUE, para além dos tribunais comuns e dos tribunais constitucionais, órgãos jurisdicionais de ordens profissionais, os tribunais arbitrais de constituição legal, os tribunais de contas no quadro da função jurisdicional, entidades administrativas com poderes jurisdicionais e as entidades reguladoras independentes com poderes jurisdicionais sancionatórios. Nestes casos, o reenvio procede se surgir a propósito de um litígio que lhe caiba legalmente dirimir. Na categoria dos candidatos negativos encontramos as autoridades administrativas, os órgãos consultivos, a procuradoria pública, a arbitragem voluntária, a conciliação, as instituições, órgãos e organismos da UE, os tribunais de Estados terceiros e os tribunais internacionais.

UNIÃO EUROPEIA. Tratado sobre o Funcionamento da União Europeia (TFUE). Artigo 267. . Disponível em: <http://eur--lex.europa.eu/legalcontent/PT/TXT/HTML/?uri=CELEX:12012E/TXT\&-from=pt>. Acesso em 15 mai. 2019. 
comprometendo a unidade do direito da UE. Em tais casos, é recomendável que o TJUE uniformize a interpretação ${ }^{56}$.

Nessas hipóteses, o TJUE faz o que a doutrina denomina de interpretação conforme, em que o tribunal deve interpretar a lei nacional em conformidade com a norma da União, para atingir o objetivo desta. A interpretação feita pelo TJUE da norma nacional não se limita aos dispositivos resultantes de transposição da DQ, mas sim de toda norma nacional, sendo permitida, inclusive, uma interpretação extensiva do direito nacional, desde que não seja contra legem ${ }^{57}$.

Consigna-se, que, apesar de que as DQs não implicam efeito direto $^{58}$, no acórdão Pupino, TJUE aceitou a obrigação de interpretar a legislação nacional em conformidade com as DQs, sob fundamento do efeito útil da decisão prejudicial, em busca do desenvolvimento de uma organização coesa e solidária na UE e do princípio da cooperação leal ${ }^{59}$. Nesse julgamento, o TJUE conferiu ao terceiro pilar uma natureza

56 BORGERS, Matthias J. Mutual Recognition and the European Court of Justice: The Meaning of Consistent Interpretation and Autonomous and Uniform Interpretation of Union Law for the Development of the Principle of Mutual Recognition in Criminal Matters. European Journal of Crime, Criminal Law and Criminal Justice, v. 18, 2010, p. 101.

57 BORGERS, Matthias J. Mutual Recognition and the European Court of Justice: The Meaning of Consistent Interpretation and Autonomous and Uniform Interpretation of Union Law for the Development of the Principle of Mutual Recognition in Criminal Matters. European Journal of Crime, Criminal Law and Criminal Justice, v. 18, 2010, p. 103.

58 Sobre o tema, CAEIRO, Pedro; FIDALGO, Sónia. O mandado de detenção europeu na experiência portuguesa: tópias da primeira década. In: Temas de Extradição e Entrega. Coimbra: Editora Almedina, 2015, p. 165: (...) apesar do seu óbvio efeito directo, uma vez que o art. $34 .^{\circ}$, n. $^{\circ}$ 2, al. b), do Tratado da União Europeia (na versão do Tratado de Amsterdã) exclui claramente o direito de os particulares invocarem o efeito directo das normas de uma decisão-quadro.

Sobre o princípio da cooperação leal, KLAMERT, Marcus. The Principle of Loyalty in EU Law. In: Oxford Studies in European Law. Oxford: Oxford University Press. 2014, p. 12, aponta que: "What is a novelty in the first part of Article 4 (3) TEU is the notion of 'sincere cooperation'. It has been argued that this merely codifi es one particular aspect of a broader principle of loyalty embodied by the entirety of Article 4 (3) TEU. However, this sentence marks the very beginning of a provision not divided into separate paragraphs. For this reason, the reference to the 'principle of sincere cooperation' could equally represent the title concept for the remainder of the duties 
autônoma, no sentido de que as leis do terceiro pilar tinham efeito na legislação nacional do EM sob suas próprias condições ${ }^{60}$.

Nesse sentido, regularmente o TJUE tem se manifestado sobre temas de cooperação judiciária, incluindo sobre a aplicação do MDE e a ausência de não execução por violação de direito fundamental, conforme será aprofundado. As considerações anteriores ajudarão a compreender o caminho que vem sendo traçado pela jurisprudência do Tribunal de Justiça das Comunidades Europeias.

\section{A proteção dos Direitos Fundamentais no Âmbito do MDE: ANÁLISE DA JURISPRUDÊNCIA DO TJUE}

\subsection{Casos Pál Aranyosi e Robert Căldăraru}

Em reenvio prejudicial, o TJUE apreciou conjuntamente os Processos C-404/15 e C-659/15 PPU, ambos apresentados pelo Tribunal Regional Superior de Bremen, Alemanha. O primeiro era relativo a dois MDEs para entrega do húngaro Pál Aranyosi às autoridades judiciárias húngaras para efeitos de procedimentos penais. No segundo processo, o romeno Robert Căldăraru foi condenado pelo Tribunal de Primeira Instância de Fagaras à pena privativa de liberdade de um ano e oito meses por condução sem carta de condução, o que motivou emissão de $\mathrm{MDE}^{61}$.

contained in Article 4 (3) TEU. I would argue, fi rstly, that there is no diff erence between the notion of sincere co operation and the notion of loyal cooperation under the Treaty. The 'principle of sincere cooperation' is rendered as ' Grundsatz der loyalen Zusammenarbeit' in the German version of the Treaty, and as 'principe de coopération loyale' in the French text. Secondly, I will argue later for considering duties of cooperation a subcategory of a more general principle of loyalty.

BORGERS, Matthias J. Mutual Recognition and the European Court of Justice: The Meaning of Consistent Interpretation and Autonomous and Uniform Interpretation of Union Law for the Development of the Principle of Mutual Recognition in Criminal Matters. European Journal of Crime, Criminal Law and Criminal Justice, v. 18, 2010, p. 102.

61 TRIBUNAL DE JUSTIÇA DA UNIÃO EUROPEIA. Acórdão C404/2015 e C-659/2015, de 5 de abril de 2016. Disponível: <http://eur-lex.europa.eu/ legal-content/PT/TXT/?qid=1557867090925\&uri=CELEX:62015CA0404>. 
Em ambos, o Ministério Público de Bremen pediu a entrega dos arguidos às respectivas autoridades. Mas o Tribunal entendeu pela ilicitude da entrega, diante de indícios de os arguidos poderiam ser sujeitos a condições de detenção que violariam o artigo $3 .^{\circ}$ da CEDH. Ressaltou que o TEDH condenou a Hungria e Romênia em razão da sobrelotação nas suas prisões e citou relatório do Comité Europeu para a Prevenção da Tortura e das Penas ou Tratamentos Desumanos ou Degradantes que apontava que as condições de detenção nos dois países não cumprem as normas mínimas previstas pelo direito internacional ${ }^{62}$.

\subsection{DeCISÃo do TRIBUNAL dE JUSTIÇA dA UnIÃo EUROPEIA}

Preliminarmente, o TJUE recordou que a DQ tem por objetivo substituir o sistema de extradição por um sistema de entrega entre autoridades judiciárias, baseando-se no princípio do reconhecimento mútuo, facilitando e acelerando a cooperação judiciária, contribuindo para

Acesso em 14 mai. 2019. Em ambos os processos, o TJUE foi provocado para que responda: 1 . Deve o artigo $1 .^{\circ}, \mathrm{n} .^{\circ} 3$, da DQ ser interpretado no sentido de que a extradição para efeitos de procedimento penal é ilícita quando existirem indícios importantes no sentido de que as condições de detenção no Estado-Membro de emissão violam os direitos fundamentais da pessoa em causa e os princípios gerais de direito previstos no artigo 6. ${ }^{\circ}$ (TUE), ou deve ser interpretado no sentido de que o Estado de execução pode ou deve, nestes casos, fazer depender a decisão sobre a admissibilidade da extradição de uma garantia do cumprimento das condições de detenção? Pode ou deve o Estado de execução para este efeito formular em concreto os requisitos mínimos das condições de detenção a garantir? 2. Devem os artigos $5 .^{\circ}$ e $6 .^{\circ}$, n. ${ }^{\circ} 1$, da [decisão-quadro] ser interpretados no sentido de que a autoridade judiciária de emissão também tem competência para [fornecer] garantias do cumprimento das condições de detenção ou deve aplicar-se a este respeito o sistema de competências interno do Estado-Membro de emissão?

62 TRIBUNAL EUROPEU DOS DIREITOS DO HOMEM. Varga e outros c. Hungria, n. ${ }^{\circ}$ 14097/12, 45135/12, 73712/12, 34001/13, 44055/13 e 64586/13, de 10 de março de 2015. Disponível: <http://hudoc.echr.coe.int/eng\#\{“fulltext”:[“14097/12"],"itemid":[“001-152784"]\}>. Acesso em 15 mai. 2019 e TRIBUNAL EUROPEU DOS DIREITOS DO HOMEM. Voicu c. Roménia, n. ${ }^{\circ}$ 22015/10; Bujorean c. Roménia, n. 13054/12; Constantin Aurelian Burlacu c. Roménia, n. ${ }^{\circ}$ 51318/12, e Mihai Laurenţiu Marin c. Roménia, n. ${ }^{\circ}$ 79857/12, de 10 de junho de 2014. Disponível: <hudoc.echr.coe.int/eng\#\{ “itemid":[“001-144664"]\}>. Acesso em 15 mai. 2019. 
tornar a União um espaço de liberdade, segurança e justiça ${ }^{63}$, com base no elevado grau de confiança que deve existir entre os EMs. Além disso, ponderou que o próprio princípio do reconhecimento mútuo assenta na confiança recíproca de que as respectivas ordens jurídicas nacionais estão em condições de fornecer uma proteção equivalente e efetiva dos DFs e que o princípio do reconhecimento mútuo, enquanto pedra angular da cooperação judiciária em matéria penal, obriga os EMs a dar seguimento a um MDE, salvo nas hipóteses taxativas da DQ.

O Tribunal, porém, defendeu que a execução do MDE só poderá ser suspensa no caso de violação grave e persistente por parte de um EM, dos valores referidos no artigo $2 .^{\circ}$ do Tratado da União Europeia e em conformidade com o processo previsto no artigo 7. ${ }^{\circ}$ do Tratado da União Europeia $^{64}$. Também admitiu a possibilidade de limitar os princípios do reconhecimento e da confiança mútuos entre EMs em circunstâncias excecionais, como violação de DF de caráter absoluto. Afirmou também que os artigos $1 .^{\circ}$ e $4 .^{\circ}$ da Carta e o artigo $3 .^{\circ}$ da CEDH consagram valores fundamentais da União, motivo pelo qual sua violação é proibida de forma absoluta, mesmo na luta contra o terrorismo e o crime organizado $^{65}$. Logo, comprovado que a entrega da pessoa possa resultar em risco de trato desumano ou degradante, à luz do padrão de proteção da $\mathrm{UE}^{66}$, a autoridade judiciária de execução poderá suspender a entrega,

${ }_{63}$ MARTIN, Maik. Franchir l'infranchissable? Coopération judiciaire et reconnaissance mutuelle dans un espace européen de justice, liberté, et sécurité. Cultures \& Conflits, n. 62, 2006, p. 63, pondera que o tratado de Amsterdã exige que os EMs desenvolvam o Espaço de liberdade, segurança e justiça por meio da cooperação judiciária.

EUROPEIA, União. Tratado de Lisboa: Tratado da União Europeia 2009. Disponível em < https://www.parlamento.pt/europa/Documents/Tratado_ Versao_Consolidada.pdf $>$. Acesso em: 15 mai. 2019.

65 Vide acórdão do TRIBUNAL EUROPEU DOS DIREITOS DO HOMEM. Bouyid c. Bélgica, n. ${ }^{\circ} 23380 / 09$, de 28 de setembro de 2015, § 81 e jurisprudência referida. Disponível: <hudoc.echr.coe.int/eng\#\{“fulltext”:[“23380”],"itemid":[“001-157670"]\}>. Acesso em 15 mai. 2019.

66 No mesmo sentido n. ${ }^{\circ} 59$ e 63 do TRIBUNAL DE JUSTIÇA DA UNIÃO EUROPEIA.Acórdão n. ${ }^{\circ} \mathrm{C}-399 / 2011$, de 26 de fevereiro de 2013. Disponível: $<$ http:// eur-lex.europa.eu/legal-content/PT/TXT/?qid=1557866964364\&uri=CELEX:62011CA0399>. Acesso em 14 mai. 2019. 
pois a execução do MDE não pode conduzir a um trato desumano ou degradante dessa pessoa.

Entretanto, a constatação de que existem motivos sérios para considerar que a pessoa correrá risco em função das condições de detenção que poderá ser submetida deve ser feita de forma objetiva, no caso concreto, com base em elementos objetivos, fiáveis, precisos e devidamente atualizados que atestem a existência dessas deficiências. Dessa forma, a mera análise de deficiências sistêmicas ou generalizadas que afetem certos grupos de pessoas ou centros de detenção no EM de emissão, não é suficiente para suspensão da execução do MDE.

Não possuindo elementos suficientes para decidir, deve-se pedir à autoridade judiciária de emissão informações complementares sobre as condições de detenção que se pretende aplicar à pessoa e informações sobre existência de procedimentos e mecanismos nacionais ou internacionais de fiscalização das condições de detenção relacionadas, que viabilizem apreciar o estado atual das condições de detenção nesses estabelecimentos.

Comprovado no caso concreto um risco de trato desumano ou degradante, ainda assim não poderá a autoridade judiciária de execução negar ou abandonar a execução do MDE, devendo adiá-la ${ }^{67}$, informando a Eurojust nos termos do artigo $17 .^{\circ}$, n. 7 , da $\mathrm{DQ}^{68}$.

67 Vide n. 38 do TRIBUNAL DE JUSTIÇA DA UNIÃO EUROPEIA. Acórdão C-237/2015, de 16 de julho de 2015. Disponível: <http://eur-lex.europa.eu/ legal-content/PT/TXT/?qid=1557871531535\&uri=CELEX:62015CA0237>. Acesso em 14 mai. 2019.

68 TRIBUNAL DE JUSTIÇA DA UNIÃO EUROPEIA. Acórdão C404/2015 e C-659/2015, de 5 de abril de 2016. Disponível: <http://eur-lex.europa.eu/ legal-content/PT/TXT/?qid=1557867090925\&uri=CELEX:62015CA0404>. Acesso em 14 mai. 2019. Dispositivo da decisão: Os artigos $1 .^{\circ}$, n. ${ }^{\circ} 3,5.0$ e 6.o, n. ${ }^{\circ}$ 1, da Decisão-Quadro 2002/584/JAI do Conselho, de 13 de junho de 2002, relativa ao mandado de detenção europeu e aos processos de entrega entre os Estados-Membros, conforme alterada pela Decisão-Quadro 2009/299/JAI do Conselho, de 26 de fevereiro de 2009, devem ser interpretados no sentido de que, perante elementos objetivos, fiáveis, precisos e devidamente atualizados que confirmem a existência de deficiências, quer sejam sistêmicas ou generalizadas, quer afetem determinados grupos de pessoas ou ainda determinados centros de detenção, no que respeita às condições de detenção no Estado-Membro de emissão, a autoridade judiciária de execução deve verificar, de maneira concreta e precisa, se existem 


\subsection{Análise da deCISÃo do Tribunal de Justiça da União EURopeia}

A decisão do TJUE resultou em profunda mudança jurisprudencial e definiu paradigmas na proteção dos DFs no espaço de liberdade, segurança e justiça, assim resumidos: a) reafirmação do princípio da confiança mútua ao limitar a não execução do MDE às hipóteses da DQ; b) adoção de natureza condicional ao princípio do reconhecimento mútuo diante da possibilidade de violação de DF absoluto; c) nivelamento entre a jurisprudência do TJUE e TEDH; d) autorização de suspensão da execução do MDE em caso de possível violação objetiva de DF absoluto ${ }^{69}$.

O TJUE sempre buscou fortalecer o princípio do reconhecimento mútuo, não sendo diferente no caso sob análise, ao limitar a não execução do MDE às hipóteses taxativas do MDE. Ainda que tenha autorizado a suspensão da execução, reforçou a obrigação de sua execução, impondo que as autoridades judiciárias empreguem esforços para viabilizar a entrega. Além disso, limitou a suspensão à hipótese de risco específico e concreto de violação a DF de carácter absoluto. Ressalta-se que, nas relações com Estado terceiros, em situação similar de potencial violação

motivos sérios e comprovados para considerar que a pessoa-objeto de um mandado de detenção europeu, emitido para efeitos de procedimento penal ou de cumprimento de uma pena privativa de liberdade, correrá, em razão das condições da sua detenção nesse Estado-Membro, um risco real de trato desumano ou degradante, na aceção do artigo $4 .^{\circ}$ da Carta dos Direitos Fundamentais da União Europeia, em caso de entrega ao referido Estado--Membro. Para o efeito, deve pedir o fornecimento de informações complementares à autoridade judiciária de emissão, que, depois de ter requerido, se necessário, a assistência da autoridade central ou de uma das autoridades centrais do Estado-Membro de emissão, na aceção do artigo $7 .^{\circ}$ da referida decisão-quadro, deve comunicar essas informações no prazo fixado nesse pedido. A autoridade judiciária de execução deve adiar a sua decisão quanto à entrega da pessoa em causa até obter as informações complementares que lhe permitam afastar a existência de tal risco. Se a existência desse risco não puder ser afastada num prazo razoável, esta autoridade deve decidir se há que pôr termo ao processo de entrega.

TRIBUNAL DE JUSTIÇA DA UNIÃO EUROPEIA. Acórdão C404/2015 e C-659/2015, de 5 de abril de 2016. Disponível: <http://eur-lex.europa.eu/ legal-content/PT/TXT/?qid=1557867090925\&uri=CELEX:62015CA0404>. Acesso em 14 mai. 2019. 
de DF (Caso Petruhhin) ${ }^{70}$, o TJUE decidiu simplesmente pelo abandono da extradição, demostrando a relevância do princípio na cooperação judiciária entre $\mathrm{EMs}^{71}$.

Entretanto, ao tempo em que reafirma o princípio do reconhecimento mútuo, esclareceu que não tem natureza incondicional. Logo, a obrigação de presumir que outros EMs asseguram uma proteção efetiva e equivalente dos DFs também não é incondicional ${ }^{72}$. Percebe-se uma aproximação entre a jurisprudência do TJUE sobre o artigo $4 .^{\circ}$ da Carta e do $\mathrm{TEDH}^{73}$ sobre o artigo $3 .^{\circ}$ da $\mathrm{CEDH}$, em especial o que foi decidido no caso Soering ${ }^{74}$, em um salutar diálogo judicial.

Nesse sentido, com objetivo de reafirmar o reconhecimento mútuo, mantendo as hipóteses de não execução às hipóteses taxativas da DQ, o TJUE ampliou as hipóteses de suspensão da execução do MDE para incluir caso de violação de DF absoluto.

70 TRIBUNAL DE JUSTIÇA DA UNIÃO EUROPEIA. Acórdão n. ${ }^{\circ}$ C-182/2016, de 6 de setembro de 2016. Disponível: <http://eur-lex.europa.eu/legal-content/PT/TXT/?qid=1557871763783\&uri=CELEX:62015CA0182>. Acesso em 14 mai. 2019.

71 RIZCALLAH, Cécilia. European and International Criminal Cooperation: A Matter of Trust?. Bruxelas: College of Europe, 2017, p. 7.

72 BOVEND'EERDT, Koen. The Joined Cases Aranyosi and Căldăraru: A New Limit to the Mutual Trust Presumption in the Area of Freedom, Security, and Justice. Utrecht Journal of International and European Law, Utrecht, v. 32, 2016, p. 113.

73 ROMERO, Marta Muñoz de Morale. Dime cómo son tus cárceles y ya veré yo si coopero. Los casos Caldararu y Aranyosi como nueva forma de entender el principio de reconocimiento mutuo. Revista para El Análisis Del Derecho. 2017, p. 4, cita: STEDH, de 24 de julio de 2012, caso Iavoc stanciu c. Rumanía, demanda $\mathrm{n}^{\circ}$ 35972/05; STEDH, de 10 de marzo de 2015, caso Varga y otros c. Hungría, demandas n ${ }^{\circ} 14097 / 12$ y otros (sentencia piloto); STEDH, de 8 de enero de 2013, caso Torregiani y otros c. Italia, demanda $\mathrm{n}^{\mathrm{o}} 43517 / 09$ y otros; STEDH, de 25 de noviembre de 2014, caso Vasilescu c. Bélgica, demanda ${ }^{\circ} 64682 / 12$.

${ }^{74}$ No Processo TRIBUNAL EUROPEU DOS DIREITOS DO HOMEM. Soering v. The United Kingdom, n. ${ }^{\circ}$ 14038/887 de julho de 1989. Disponível: <hudoc.echr.coe.int/eng\#\{“fulltext”:[“14038/88”],"itemid":[“001-57619”]\}>. Acesso em 15 mai. 2019, o TEDH determinou a não extradição, por ter sido demonstrado motivos substanciais para acreditar que a pessoa em causa, se extraditada, enfrentaria o risco real de ser submetida a tortura ou a tratamentos desumanos ou degradantes no país requerente. 
Mas, para ser capaz de resultar em suspensão, a análise da possibilidade de violação de DF deve ser feita em duas etapas. Na primeira a autoridade judiciária de execução verificará existência de deficiências sistêmicas ou generalizadas, ou que possam afetar certos grupos de pessoas ou certos locais de detenção, com base nas informações que dispuser, incluindo decisões de tribunais internacionais como o TEDH, relatórios ou outros documentos produzidos por órgãos do Conselho da Europa ou sob a égide da $\mathrm{ONU}^{75}$. Em caso positivo, deve fazer uma segunda análise, específica e precisa, de motivos substanciais para acreditar que o indivíduo em questão estará exposto a esse risco se entregue, podendo solicitar informações complementares para fundamentar sua decisão. Na análise do risco específico, é imprescindível o grau de impacto que entrega resultaria sobre os DFs da pessoa, individualizando o risco genérico. Assim, riscos meramente genéricos não são suficientes para fundamentar uma recusa, mas apenas autorizam uma análise do risco específico ${ }^{76}$.

Diante da suspensão da execução do MDE, a manutenção da pessoa em detenção pode se mostrar desproporcional ou injustificável, o que autoriza sua liberdade provisória, com adoção de medidas necessárias para evitar a fuga da pessoa reivindicada ${ }^{77}$.

A autoridade judiciária de emissão pode, por meio de informações complementares, superar o risco específico, por meio de medidas alternativas destinadas à pessoa, como, por exemplo, que a pena seja cumprida em estabelecimento adequado que respeite as normas internacionais, ou mesmo demostrando que o risco não mais existe, o que permitirá que a autoridade judiciária de execução autorize a entrega ${ }^{78}$, ainda que tenham

75 RIZCALLAH, Cécilia. European and International Criminal Cooperation: A Matter of Trust?. Bruxelas: College of Europe, 2017, p. 5.

76 ROMERO, Marta Muñoz de Morale. Dime cómo son tus cárceles y ya veré yo si coopero. Los casos Caldararu y Aranyosi como nueva forma de entender el principio de reconocimiento mutuo. Revista para El Análisis Del Derecho. 2017, f. 8.

77 ROMERO, Marta Muñoz de Morale. Dime cómo son tus cárceles y ya veré yo si coopero. Los casos Caldararu y Aranyosi como nueva forma de entender el principio de reconocimiento mutuo. Revista para El Análisis Del Derecho. 2017, f. 10. veré yo si coopero. Los casos Caldararu y Aranyosi como nueva forma de 
sido extrapolados os prazos de execução do MDE previstos na DQ. Pois, conforme decidido no caso Lanigan, findo o prazo de execução, a autoridade judiciária de exceção ainda deve cumprir o $\mathrm{MDE}^{79}$.

Caso as informações complementares não permitam concluir pela superação do risco específico, a entrega não poderá ser feita, devendo ser adiada (termos previstos no artigo 17.4 DQ), com comunicação à Eurojust indicando os motivos da demora ${ }^{80}$.

Ainda que na decisão sob análise, assim como no parecer do Advogado-Geral, não tenha ficado explícito, criou-se uma nova hipótese de entrega condicional, fundado no princípio da cooperação leal e da

entender el principio de reconocimiento mutuo. Revista para El Análisis Del Derecho. 2017, f. 15.

79 TRIBUNAL DE JUSTIÇA DA UNIÃO EUROPEIA. Acórdão nº C-237/2015315/01, de 16 de junho de 2015. Disponível: <eur-lex.europa.eu/legal-content $/ \mathrm{PT} / \mathrm{TXT} /$ ?qid=1557867378681\&uri=CELEX:62015CA0237>. Acesso em 14 mai. 2019, em que o tribunal decidiu que "Os artigos $15 .^{\circ}$, n. ${ }^{\circ} 1$, e $17 .^{\circ}$ da Decisão-Quadro 2002/584/JAI do Conselho, de 13 de junho de 2002, relativa ao mandado de detenção europeu e aos processos de entrega entre os Estados-Membros, conforme alterada pela Decisão-Quadro 2009/299/ JAI do Conselho, de 26 de fevereiro de 2009, devem ser interpretados no sentido de que a autoridade judiciária de execução continua obrigada a adotar a decisão sobre a execução do mandado de detenção europeu findos os prazos fixados nesse artigo $17 .^{\circ}$. O artigo $12 .^{\circ}$ da referida decisão-quadro, lido em conjugação com o artigo $17 .^{\circ}$ desta e à luz do artigo $6 .^{\circ}$ da Carta dos Direitos Fundamentais da União Europeia, deve ser interpretado no sentido de que não se opõe, em tal situação, à manutenção da pessoa procurada em detenção, em conformidade com o direito do Estado-Membro de execução, ainda que a duração total dos períodos de detenção dessa pessoa exceda aqueles prazos, desde que esta duração não seja excessiva tendo em conta as características do procedimento seguido no processo principal, o que cabe ao órgão jurisdicional de reenvio verificar. Se a autoridade judiciária de execução decidir pôr termo à detenção da referida pessoa, deverá acompanhar a libertação provisória dessa pessoa de todas as medidas que considere necessárias para evitar a sua fuga e para garantir que as condições materiais necessárias à sua entrega efetiva continuem reunidas enquanto não for tomada nenhuma decisão definitiva sobre a execução do mandado de detenção europeu.

80 TRIBUNAL DE JUSTIÇA DA UNIÃO EUROPEIA. Acórdão C404/2015 e C-659/2015, de 5 de abril de 2016. Disponível: <http://eur-lex.europa.eu/ legal-content/PT/TXT/?qid=1557867090925\&uri=CELEX:62015CA0404>. Acesso em 14 mai. 2019. 
confiança mútua, ao condicionar a entrega a que o EM de emissão tome todas as medidas necessárias para garantir o respeito pelos $\mathrm{DFs}^{81}$.

Com a decisão em análise, o TJUE passa a admitir, excepcionalmente, a possibilidade de suspensão da execução do MDE por violação de DF absoluto, contrastando com a posição defendida no caso Radu ${ }^{82}$, conciliando a tutela dos DFs com o princípio do reconhecimento mútuo.

\section{Considerações finais}

A supressão das fronteiras internas dos EMs - e a consequente livre circulação de pessoas, mercadorias e serviços - não poderia ser feita em detrimento da segurança, da ordem e das liberdades públicas ${ }^{83}$, o que exigiu o aperfeiçoamento do sistema de cooperação judiciária em matéria penal. Fundamentado no princípio do reconhecimento mútuo, o legislador da UE criou mecanismos para facilitar o alcance

81 TRIBUNAL DE JUSTIÇA DA UNIÃO EUROPEIA. Acórdão C404/2015 e C-659/2015, de 5 de abril de 2016. Disponível: <http://eur-lex.europa.eu/ legal-content/PT/TXT/?qid=1557867090925\&uri=CELEX:62015CA0404>. Acesso em 14 mai. 2019.

82 No TRIBUNAL DE JUSTIÇA DA UNIÃO EUROPEIA. Acórdão C-396/11, de 12 de outrubro de 2012. Disponível em:<http://eur-lex.europa.eu/legal-content/PT/TXT/?qid=1557865541872\&uri=CELEX:62011CC0396>. Acesso em 14 mai. 2019, o TJUE consignou no item 36 que "os Estados-Membros apenas podem recusar dar execução a tal mandado nos casos de não execução obrigatória previstos pelo artigo $3 .^{\circ}$ desta assim como nos casos de não execução facultativa enumerados nos seus artigos $4 .^{\circ}$ e $4 .^{\circ}$-A (v., neste sentido, acórdãos de $1 .^{\circ}$ de dezembro de 2008, Leymann e Pustovarov, C-388/08 PPU, Colet., p. I-8983, n. o 51, e de 16 de novembro de 2010, Mantello, C-261/09, Colet., p. I-11477, n. o 37). Além disso, a autoridade judiciária de execução apenas pode subordinar a execução de um mandado de detenção europeu às condições definidas no artigo $5 .^{\circ}$ da referida decisão-quadro. Ao final, concluiu no item 43 que "Tendo em conta o exposto, há que responder às quatro primeiras questões, bem como à sexta questão, que a Decisão-Quadro 2002/584 deve ser interpretada no sentido de que as autoridades judiciárias de execução não podem recusar executar um mandado de detenção europeu emitido para efeitos de um procedimento penal com o fundamento de que a pessoa procurada não foi ouvida no Estado-Membro de emissão antes de esse mandado de detenção ter sido emitido”.

83 RODRIGUES, Anabela Miranda; DA MOTA, José Luís Lopes. Para uma política criminal europeia. Coimbra: Editora Coimbra. 2002, p. 33. 
transfronteiriço em matéria penal, com significativo impacto nos direitos processuais das pessoas, mas com pouca atenção legislativa aos desafios da proteção dos $\mathrm{DFs}^{84}$.

Apesar da importância do reconhecimento mútuo para consolidação do direito da UE, este princípio não pode ser absoluto, principalmente quando se sai da esfera meramente econômica e parte para o domínio penal, em que o indivíduo é sujeito das consequências do MDE, o que faz surgir a necessidade de gerenciamento do princípio no sentido de cumprir a proporcionalidade ${ }^{85}$ para então a noção de confiança, como pedra central, poder funcionar plenamente $^{86}$. Nesse sentido, o reconhecimento mútuo não deve triunfar automaticamente sobre os DFs, conforme decidiu o TJUE ${ }^{87}$. Porém, instituir um controle em todos os casos esvaziaria o conteúdo do princípio, mas isso não pode impedir, em caráter excepcional, o controle da proteção dos DFs.

Sem dúvida, não apenas em relação ao MDE, mas em todas as formas de cooperação fundadas na confiança mútua, a grande questão será definir o equilíbrio entre a necessidade de uma cooperação célere e eficaz e a preservação dos DFs, reconhecendo que o princípio de

${ }^{84}$ LÖÖF, Robin. Shooting from the hip: Proposed minimum rights in criminal proceedings throughout the EU. European Law Journal, Oxford, v. 12, n. 3, p. 421-430, 2006, p. 423.

Sobre a forma de abordagem do princípio da proporcionalidade pelo TJUE, SILVA, Suzana Tavares da. O tetralemma do controlo judicial da proporcionalidade no contexto da universalização do princípio: adequação, necessidade, ponderação e razoabilidade. In Boletim da Faculdade de Direito. Coimbra: vol. 88, tomo II, 2012, p. 669: As referências às diferentes concepções e aplicações do princípio da proporcionalidade permitiram-nos compreender que ele admite diversas combinações: (...) iii) um controlo duplo fundado nos testes da necessidade e da proporcionalidade em sentido restrito, divulgado sobretudo na jurisprudência do Tribunal de Justiça da União Europeia;

86 HERLIN-KARNELL, Ester. European arrest warrant Cases and the Principles of Non-discrimination and EU Citizenship. The Modern Law Review Limited, Oxford, v. 73, ${ }^{\circ}$ 5, p. 824-835, 2010, p. 832.

87 TRIBUNAL DE JUSTIÇA DA UNIÃO EUROPEIA. Acórdão C-411/10 e C-493/10, de 21 de dezembro de 2011. Disponível em:<http://eeur-lex. europa.eu/legal-content/PT/TXT/?qid=1557867705185\&uri=CELEX:62010CA0411>. Acesso em 14 mai. 2019. 
reconhecimento mútuo não resulta numa presunção absoluta do respeito aos DFs por todos $\mathrm{EMs}^{88}$.

O acórdão dos casos Ranyosi e Caldararu estabeleceu, pela primeira vez, um limite à entrega na execução do MDE não expressamente prevista na $\mathrm{DQ}$, permitindo à autoridade judiciária de execução conciliar a salvaguarda da soberania e evitar a impunidade por meio da cooperação e do respeito aos $\mathrm{DFs}^{89}$.

No caso, o TJUE adotou entendimento há muito defendido por Rodrigues, no sentido de que, apesar de o considerando n. ${ }^{\circ} 10$ não constar das disposições da DQ e de ser discutível se possuiu natureza jurídica de norma, deve prevalecer uma interpretação em prol dos DFs, posição que encontra apoio também nos considerandos $\mathrm{n} .^{0} 12 \mathrm{e} \mathrm{n}^{\mathrm{o}} 13^{90}$.

Melhor teria sido se o legislador europeu, ciente da necessidade de instrumentos efetivos de proteção dos DFs, tivesse expressamente previsto uma hipótese de não execução humanitária. Como não o fez, coube ao TJUE encontrar uma solução.

Em última análise, a decisão pode contribuir para uniformização do padrão das detenções dos EMs, com melhoras daquelas que não atendem os padrões mínimos da UE, sob pena do EM que não o fizer se ver privado do direito de entrega. Mas, sem dúvida, a decisão busca evitar que a violação a DF se torne motivo de não execução automática, fundando-se no princípio da proporcionalidade ${ }^{91}$, na medida em que

88 PÉREZ, Aida Torres. Spanish Constitutional Court Constitutional Dialogue on the European arrest warrant: The Spanish Constitutional Court Knocking on Luxembourg's Door; Spanish Constitutional Court, Order of 9 June 2011. European Constitutional Law Review, Cambridge, v. 8, n 1, p. 105-127, 2012, p. 126. ROMERO, Marta Muñoz de Morale. Dime cómo son tus cárceles y ya veré yo si coopero. Los casos Caldararu y Aranyosi como nueva forma de entender el principio de reconocimiento mutuo. Revista para El Análisis Del Derecho. 2017, f. 23.

RODRIGUES, Anabela Miranda. O mandado de detenção europeu - Na via da construção de um sistema penal europeu: um passo ou um salto?. Revista Portuguesa de Ciência Criminal, Porto, ano 13, n. 1, 2003, p. 47.

91 Sobre proporcionalidade, TRIBUNAL DE JUSTIÇA DA UNIÃO EUROPEIA. Conclusões do Advogado-Geral Yves Bot, Processo C-404/15 e 659/2015, de 03 de março de 2016. Disponível em:<http://eur-lex.europa.eu/legal-content/PT/TXT/?qid=1557867910754\&uri=CELEX:62015CC0404>. Acesso em 14 mai. 2019: 170. Tratando-se de um mandado de detenção europeu 
somente admitiu a não entrega em situações excepcionais, ciente do impacto que teria no sistema.

Por outro lado, apesar de a decisão ter limitado o alcance do reconhecimento mútuo, não se pode esquecer da relação necessária e paradoxal entre o direito penal e os DFs, que legitima a repressão punitiva em nome da proteção (função espada), em que os DFs traduzem a boa consciência da punição, ao tempo que também representam uma limitação da punição do direito penal (função escudo), exprimindo o princípio da proporcionalidade em sentido amplo e a necessidade de intervenção penal ${ }^{92}$.

Considerando que o respeito aos DFs constitui verdadeiro patrimônio europeu, não se situando numa lógica de confiança ou desconfiança recíproca, por se tratar de questão de garantia concreta e não ilusória ${ }^{93}$, parece ter sido acertada a decisão.

O papel do direito penal na proteção das futuras gerações é um problema relativamente novo que põe em causa os próprios fundamentos e a legitimação da intervenção penal, a idoneidade dos seus instrumentos e o caminho do labor jurídico-científico que exerce ${ }^{94}$. Os meios de cooperação judiciária na UE, de igual forma, precisam ser pensados e usados em pleno respeito aos DFs. Somente assim os EMs e a UE manterão a

emitido para efeitos de procedimento penal, este é proporcionado se as suas condições de execução forem compatíveis com a simples necessidade de manter a pessoa procurada à disposição da justiça. Aliás, no seu acórdão Ladent c. Polónia 54, o Tribunal Europeu dos Direitos do Homem declarou que a emissão de um mandado de detenção europeu pela prática de uma infração relativamente à qual a prisão preventiva seria normalmente considerada inapropriada pode acarretar consequências desproporcionadas para a liberdade da pessoa procurada, suscetíveis de serem enquadradas no âmbito das garantias previstas no artigo $5 .^{\circ}$ da CEDH.

92 RODRIGUES, Anabela Miranda. Direito penal europeu pós-Lisboa. Um direito penal funcionalista. Revista de legislação e jurisprudência, Coimbra, n. ${ }^{\circ}$ 4004, p. 320/334, 2017, p. 331.

93 RODRIGUES, Anabela Miranda. O mandado de detenção europeu - Na via da construção de um sistema penal europeu: um passo ou um salto?. Revista Portuguesa de Ciência Criminal, Porto, ano 13, n. 1, 2003, p. 48.

94 FIGUEIREDO DIAS, José de. O papel do direito penal na proteção das gerações futuras. In: SILVA, Luciano Nascimento. In: SILVA, Luciano Nascimento. Estudos jurídicos de Coimbra. Curitiba: Jurua Editora, 2007, p. 22. 
legitimidade necessária para intervenção penal na proteção das futuras gerações. O direito penal europeu deve ser aferido pelo princípio da proporcionalidade em sentido amplo, configurando um verdadeiro limite para frear os efeitos expansivos decorrentes do princípio da eficácia do direito da UE ${ }^{95}$.

Não se pode esquecer que o direito é algo dinâmico e assim tem que ser, sendo o direito europeu mais ainda, o que exige, por meio da percepção daquilo que constitui o real da contemporaneidade, "lançar novos modos de realização do direito, para que este continue a ser, não só um pressuposto para a realização de tantos outros valores, mas também, ele próprio, projeção, no futuro, dos seus valores específicos ${ }^{96 "}$.

Concluo que a decisão do TJUE conseguiu equilibrar a necessidade de respeitar o princípio do reconhecimento mútuo, a proporcionalidade na implementação e na aplicação da DQ, mantendo o respeito dos DFs, ao mesmo tempo em que permitiu a implementação de uma política-criminal da União, interpretando as normas nacionais (alemã, mas extensível àquelas que tenham previsão semelhante) conforme o direito comunitário, constituindo não apenas um ordenamento de segurança, mas, nas palavras de Rodrigues, também de liberdade ${ }^{97}$.

95 RODRIGUES, Anabela Miranda. Direito penal europeu pós-Lisboa. Um direito penal funcionalista. Revista de legislação e jurisprudência, Coimbra, n. ${ }^{\circ}$ 4004, p. 320/334, 2017, p. 332.

96 FARIA COSTA, José. O Direito Penal e o Tempo: algumas reflexões dentro do nosso tempo e em redor da prescrição. Boletim da Faculdade de Direito da Universidade de Coimbra. Volume comemorativo do $75^{\circ}$ tomo do Boletim da Faculdade de Direito, p. 1139-1165, 2003, p. 149.

97 RODRIGUES, Anabela Miranda. Direito penal europeu pós-Lisboa. Um direito penal funcionalista. Revista de legislação e jurisprudência, Coimbra, n. ${ }^{\circ} 4004$, p. 320/334, 2017, p. 334, afirma que: O direito penal europeu esteve, na sua origem e desenvolvimentos primeiros, ligado mais ao interesse de punir dos Estados-Membros e menos à proteção dos direitos fundamentais. Este é o tempo de o direito penal europeu dar sinais inequívocos de que está ao serviço, da vítima e do condenado. E, assim, de se construir, não como um ordenamento de segurança, mas como um ordenamento de liberdade. 


\section{REFERÊNCIAS}

BORGERS, Matthias J. Mutual Recognition and the European Court of Justice: The Meaning of Consistent Interpretation and Autonomous and Uniform Interpretation of Union Law for the Development of the Principle of Mutual Recognition in Criminal Matters. European Journal of Crime, Criminal Law and Criminal Justice, v. 18, 2010.

BOVEND’EERDT, Koen. The Joined Cases Aranyosi and Căldăraru: A New Limit to the Mutual Trust Presumption in the Area of Freedom, Security, and Justice. Utrecht Journal of International and European Law, Utrecht, v. 32, 2016.

CAEIRO, Pedro. O procedimento de entrega previsto no Estatuto de Roma e sua incorporação no Direito português. IN: MOREIRA, Vital. O Tribunal Penal Internacional e ordem jurídica portuguesa. Coimbra: Editora Coimbra, p. 69-157, 2004.

CAEIRO, Pedro. Cooperação judiciária na União Europeia. In: Direito penal económico e europeu: Textos doutrinários. Volume III, p. 69-80. Coimbra: Editora Coimbra, 2009.

CAEIRO, Pedro; FIDALGO, Sónia. O mandado de detenção europeu na experiência portuguesa: tópias da primeira década. In: Temas de Extradição e Entrega. Coimbra: Editora Almedina, p. 159-194, 2015.

COSTA, João Pedro Lopes. A dupla incriminação no mandado de detenção europeu e o verdadeiro alcance da abolição do seu controlo. In: Temas de Extradição e Entrega. Coimbra: Editora Almedina, p. 82-113, 2015.

FARIA COSTA, José. O Direito Penal e o Tempo: algumas reflexões dentro do nosso tempo e em redor da prescrição. Boletim da Faculdade de Direito da Universidade de Coimbra. Volume comemorativo do $75^{\circ}$ tomo do Boletim da Faculdade de Direito, p. 1139-1165, 2003.

FIGUEIREDO DIAS. José de. O papel do direito penal na proteção das gerações futuras. In: SILVA, Luciano Nascimento. In: SILVA, Luciano Nascimento. Estudos jurídicos de Coimbra. Curitiba: Jurua Editora, 2007.

FICHERA, Massimo. The European arrest warrant and the Sovereign State: A Marriage of Convenience?. European Law Journal, Oxford, v. 15, n. 1, p. 70-97, 2009.

FORST, Rainer. The justification of basic rights: A discourse-theoretical approach. Netherlands Journal of Legal Philosophy, v. 45, p. 7-28, 2016.

HERLIN-KARNELL, Ester. European arrest warrant Cases and the Principles of Non-discrimination and EU Citizenship. The Modern Law Review Limited, Oxford, v. 73, ${ }^{\circ} 5$, p. 824-835, 2010. 
KLIMEK, Libor. New law on the European arrest warrant in the Slovak Republic: does it fulfil standards at the level of the EU. European Journal of Crime \& Criminat Law and Criminat Justice, v. 20, p. 181-192, 2012.

KLAMERT, Marcus. The Principle of Loyalty in EU Law. In: Oxford Studies in European Law. Oxford: Oxford University Press. 2014.

LÖÖF, Robin. Shooting from the hip: Proposed minimum rights in criminal proceedings throughout the EU. European Law Journal, Oxford, v. 12, n. 3, p. 421-430, 2006.

MACHADO, Jónatas Eduardo Mendes. Direito da União Europeia. Coimbra: Editora Coimbra. $2^{\mathrm{a}}$ Edição. 2014.

MARTIN, Maik. Franchir l'infranchissable? Coopération judiciaire et reconnaissance mutuelle dans un espace européen de justice, liberté, et sécurité. Cultures \& Conflits, n. 62, p. 63-77, 2006.

MOREIRA, Vital. A ‘Constitucionalização' dos Direitos Fundamentais na União Europeia (UE). In: Estudos em Homenagem ao Conselheiro José Manuel Cardoso da Costa. Coimbra: Coimbra Editora, 2003.

MOURA RAMOS, Rui Manuel Moura. Situação e Desafios da Protecção dos Direitos Fundamentais na União Europeia. Disponível em: http://scielo.mec.pt/scielo. php?script=sci_arttext\&pid=S2183-184X2018000200002. Acesso em: 02 jan. 2019. PÉREZ, Aida Torres. Spanish Constitutional Court Constitutional Dialogue on the European arrest warrant: The Spanish Constitutional Court Knocking on Luxembourg's Door; Spanish Constitutional Court, Order of 9 June 2011. European Constitutional Law Review, Cambridge, v. 8, n 1, p. 105-127, 2012.

RIZCALLAH, Cécilia. European and International Criminal Cooperation: A Matter of Trust?. Bruxelas: College of Europe, 2017.

RODRIGUES, Anabela Miranda; DA MOTA, José Luís Lopes. Para uma política criminal europeia. Coimbra: Editora Coimbra. 2002.

RODRIGUES, Anabela Miranda. O mandado de detenção europeu - Na via da construção de um sistema penal europeu: um passo ou um salto?. Revista Portuguesa de Ciência Criminal, Porto, ano 13, n. 1, p. 27-63, 2003.

RODRIGUES, Anabela Miranda. O direito penal europeu emergente. Coimbra: Editora Coimbra. 2008.

RODRIGUES, Anabela Miranda. A globalização do direito penal - Da pirâmide à rede ou entre a unificação e a harmonização. In Direito penal económico e europeu: Textos doutrinários. Volume III. Editora Coimbra. 2009. 
RODRIGUES, Anabela Miranda. Direito penal europeu pós-Lisboa. Um direito penal funcionalista. Revista de legislação e jurisprudência, Coimbra, n. ${ }^{\circ} 4004$, p. 320-334, 2017.

ROMERO, Marta Muñoz de Morale. Dime cómo son tus cárceles y ya veré yo si coopero. Los casos Caldararu y Aranyosi como nueva forma de entender el principio de reconocimiento mutuo. Revista para El Análisis Del Derecho. 2017.

SCHALLMOSER, Nina Marlene. The European arrest warrant and Fundamental Rights. Risks of Violation of Fundamental Rights through the EU Framework Decision in Light of the ECHR. European Journal of Crime, Criminal Law and Criminal Justice, v. 22, p. 135-165, 2014.

SILVA, Suzana Tavares da. O tetralemma do controlo judicial da proporcionalidade no contexto da universalização do princípio: adequação, necessidade, ponderação e razoabilidade. In Boletim da Faculdade de Direito. Coimbra: vol. 88, tomo II, p. 639-678, 2012.

SILVEIRA, Alessandra. Do âmbito de aplicação da Carta dos Direitos Fundamentais da União Europeia: recai ou não recai? - Eis a questão! Julgar, Coimbra, n. 22, p. 179-209, 2014.

\section{Informações adicionais e declarações dos autores (integridade científica)}

Declaração de conflito de interesses (conflict of interest declaration): o autor confirma que não há conflitos de interesse na realização das pesquisas expostas e na redação deste artigo.

Declaração de autoria e especificação das contribuições (declaration of authorship): todas e somente as pessoas que atendem os requisitos de autoria deste artigo estão listadas como autores; todos os coautores se responsabilizam integralmente por este trabalho em sua totalidade.

Declaração de ineditismo e originalidade (declaration of originality): o autor assegura que o texto aqui publicado não foi divulgado anteriormente em outro meio e que futura republicação somente se realizará com a indicação expressa da referência desta publicação original; também atesta que não há plágio de terceiros ou autoplágio. 
Dados do processo editorial

(http://www.ibraspp.com.br/revista/index.php/RBDPP/about/editorialPolicies)

- Recebido em: 01/04/2019

- Controle preliminar e verificação de plágio: 01/04/2019

- Avaliação 1: 21/04/2019

- Avaliação 2: 22/04/2019

- Avaliação 3: 28/04/2019

Equipe editorial envolvida

- Editor-chefe: 1 (VGV)

- Editor-associado: 1 (PC)

- Editora-assistente: 1 (MJV)

- Revisores: 3

- Decisão editorial preliminar: 14/05/2019

- Retorno rodada de correções: 22/05/2019

- Decisão editorial final: 23/05/2019

\section{COMO CITAR ESTE ARTIGO:}

LEAL, Celso Costa Lima. A Tutela dos Direitos Fundamentais no Âmbito do Mandado de Detenção Europeu: Análise da Jurisprudência do Tribunal de Justiça da União Europeia. Revista Brasileira de Direito Processual Penal, Porto Alegre, vol. 5, n. 2, p. 855-888, mai./ago. 2019.

https://doi.org/10.22197/rbdpp.v5i2.218

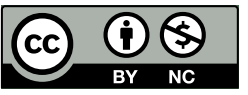

Esta obra está licenciada com uma Licença Creative Commons Atribuição-NãoComercial 4.0 Internacional. 